UDC 911.3:338.4

Volodymyr Stefanovych Grytsevych,

$\mathrm{PhD}$ (Geography), Associate Professor, Department of Economic and Social Geography,

Ivan Franko National University of Lviv,

PO Box 2137, Lviv-7, 79007, Ukraine,

e-mail: gvsmg@ukr.net, https://orcid.org/0000-0002-0278-7332;

Khrystyna Yevgenivna Podvirna,

$\mathrm{PhD}$ (Geography), Associate Professor of the Department of International Economics and Investment,

Lviv Institute of Economics and Tourism,

8 Mentsynskyi str., Lviv, 79007, Ukraine,

e-mail: khrystyna.pod@gmail.com, https://orcid.org/0000-0002-0828-9078;

Mariana Igorivna Senkiv,

$\mathrm{PhD}$ (Geography), Assistant of the Department of Tourism, Lviv Polytechnic National University,

130 General Chuprynka str., Lviv, 79057, Ukraine,

e-mail: mariana.i.senkiv@lpnu.ua, https://orcid.org/0000-0002-2146-3456

\title{
MOTOR TRANSPORT NETWORK IN THE WESTERN REGION OF UKRAINE AS A FACTOR OF TOURISM INDUSTRY DEVELOPMENT
}

В. С. Грицевич, Х. С. Подвірна, М. І. СеньКів. АВТОТРАНСПОРТНА МЕРЕЖА ЗАХІДНОГО РЕГІОНУ УКРАЇНИ ЯК ЧИННИК РОЗВИТКУ ТУРИСТИЧНӦ̈ ГАЛУЗІ. У представленій статті вивчено суспільно-географічні особливості взаємного впливу автотранспортної мережі великого міжсбласного регіону та туристичної галузі ивого ж регіону. Охарактеризовано в розрізі восьми областей Західного регіону України мережу автомобільних шляхів за значенням (міжнародні, національні, регіональні та інші) і п'ятьма категоріями, середня обласна щільність автомобільних доріг загального користування, головні пункти та вузли автотранспортної мережі, представлена аналітична картосхема иієї мережі. Вивчено динаміку потоків іноземних туристів, а також туристів-громадян, які виїжджали за кордон у Західному регіоні Україні протягом 2000-2017 рр. Охарактеризовано рекреаційно-туристичний потенціал Західного регіону Украйни, щзо свідчить про його хорошу потенційну привабливість для залучення внутрішніх та зовнішніх інвестицій щодо подальшого вдосконалення транспортної та туристичної інфраструктури. Виділено специфічні для регіону види туризму, які вже отримали розвиток, а також мають великі шанси для розвитку в близькому майбутньому. Проаналізовано автотранспортну доступність видів туризму за способом пересування (автомобільний, велосипедний, пішохідний, річковий) та за метою поїдки (професійно-діловий, пізнавальний, оздоровчий, паломницький, ностальгійний, рибальський, мисливський) для усіх п'яти категорій автомобільних доріг, а також для місиевості поза дорогами. Отримані відповідності мають загальний трендовий характер і дозволяють існування винятків для окремих унікальних ситуацій. 3'ясовано, щьо види туризму, виділені за способом пересування, можна лінійно впорядкувати відповідно до переважаючої категорії автомобільних доріг. Встановлено, щзо види туризму, виділені за метою поїзки, також можна лінійно впорядкувати відповідно до переважаючої категорії автомобільних доріг.

Ключові слова: автотранспорт, дороги, мережа, туризм, потік, доступність, область, регіон.

В. С. Грицевич, К. Е. Подвирна, М. И. Сенькив. АВТОТРАНСПОРТНАЯ СЕТЬ ЗАПАДНОГО РЕГИОНА УКРАИНЫ КАК ФАКТОР РАЗВИТИЯ ТУРИСТИЧЕСКОЙ ОТРАСЛИ. В представленной статье изучены общественногеографические особенности взаимного влияния автотранспортной сети большого межобластного региона и туристической отрасли этого же региона. Охарактеризована в разрезе восьми областей Западного региона Украины сеть автомобильных дорог по значению (международные, начиональные, региональные и другие) и пяти категориям, средняя областная плотность автомобильных дорог общего пользования, главные пункты и узль автотранспортной сети, представлена аналитическая картосхема этой сети. Изучена динамика потоков иностранных туристов, а также туристов-граждан, выезжавших за гранииу в Западном регионе Украины в течение 2000-2017 г2. Произведён анализ рекреационнотуристического потенциала Западного региона Украины, свидетельствующиий о его хорошей потенциальной привлекательности для привлечения внутренних и внешних инвестиций по дальнейшему совершенствование транспортной и туристической инфраструктуры. Выделены специфические для региона виды туризма, которые уже получили развитие, а такље имеют большие шансы для развития в ближайшем будущем. Проанализирована автотранспортная доступность видов туризма по способу передвижения (автомобильный, велосипедный, пешеходный, речной) и по иели поездки (профессионально-деловой, познавательный, оздоровительный, паломнический, ностальгический, рыболовный, охотничий) для всех пяти категорий автомобильных дорог, а также для местности вне дорог. Полученные соответствия имеют общий трендовый характер и допускают существование исключений для отдельных уникальных ситуачий. Установлено, что виды туризма, выделенные по способу передвижения, можно линейно упорядочить в соответствии с преобладающей категорией автомобильных дорог. Установлено, что виды туризма, выделенные по иели поездки, можно линейно упорядочить в соответствии с преобладающей категорией автомобильных дорог.

Ключевые слова: автотранспорт, дороги, сеть, туризм, поток, доступность, область, регион.

Formulation of the problem. In human geography, the problem of studying the mutual influence of infrastructure and services is important. Infrastructure development can be a factor in the development of certain industries (or types of economic activity) in the service sector. Conversely, the development of the service sector may stimulate infrastructure development to increase profits from joint activity. 
Analysis of recent research and publications. The study of this issue is focused on relatively few publications. In the paper [16] the category of human and geographical knowledge of the world is proposed, the forms of volatility and organization of the world are described, the connection of the population movement with its potential is shown, and the population groups are listed in relation to its social movement. Based on the study of the transport networks in the Carpathian region of Ukraine, definitions of the concepts of a multimodal transport line, a multimodal route, a multimodal transport node and related concepts have been given by the authors [15]. Classification of the transport nodes has been carried out, the international transport corridors of the region in connection with the multimodal routes as well as the graph of the multimodal routes of the Carpathian region of Ukraine have been studied, and the problems of their territorial organization have been discovered. The motor transport microposition in urban settlements in the Western region of Ukraine has been studied and its impact on transport and logistics activities in the region has been analyzed by the authors [13]. The topology of the motor transport network of the Western region of Ukraine has been characterized by oblasts. The relations between transport and logistics activities and characteristics of graph of the motor transport network have been established. In the paper [10] a system of mathematical and geographic models of the hotel industry of the region, a method for calculating the integral indicator of hotel establishments of the district for absolute indicators has been developed. Relative indicators of the first and second levels, the integral index of absolute features for hotel establishments of the region is analyzed, the state of international tourism in hotel establishments of Lviv oblast is studied. The paper [11] highlights contemporary regional and dynamic aspects of international tourism in the Carpathian region of Ukraine. The authors analyzed the quantitative dynamics of international tourism in this region during 2000-2010 within the administrative oblasts of the region. Administrative oblasts with a high and average share of tourists traveling abroad are indicated. A comparative description of these indicators with those of 2004 has been carried out. In the paper [19] logistic mechanisms of international tourism activity of Ukraine is analyzed, factors of development of international tourism in Ukraine, characteristics of international tourist flows and financial flows in international tourism of Ukraine are presented. The influence of international transport corridors on the development of logistics of international tourism in Ukraine is studied. In the paper [17] the authors have studied distribution of logistic companies in the oblasts of the Western Ukrainian borderland, identified the main logistical centers within them. Transport and distribution logistics subjects in oblasts of the Western Ukrainian borderland were studied. Railway and automobile networks in western oblasts, features of railway and automobile cargo flows there have been described. The method of numerical estimation of transport and logistics potential index for the border oblasts is proposed. Transport and logistics index of the oblasts of the Western Ukrainian borderland has been calculated.

Direct relationship of global tourism growth with a significant increase in transport networks has been noted by the authors [18]. Transport is considered through various levels, including the level of interstate regulation, national government and how this affects forms of tourism, as well as marketing and management of transport operations. In addition, article [20] provides conclusions on the future of transport and tourism, including the management of environmental impacts and new forms of tourism related transport. The article analyzes vehicles used by the largest tour operators in Poland. The study is based on in-depth analysis and use of tourism and transport resources. The results show a large concentration of services for organized tourist traffic on a small number of wholesale transport intermediaries. In general, the analysis shows the leisure travel market in Poland, as being in the early stages of development.

Selection of previously unsettled parts of the general problem. In this research the motor transport infrastructure of the region as part of general infrastructure is considered, and tourism industry of the region as part of service sector. This allows to specify and to study in-depth the peculiarities and specifics of the mutual influence of the motor transport network and specific types of tourism in the Western region of Ukraine.

Formulating the purpose of the paper. The purpose of the paper is to analyze the motor transport network in the Western region of Ukraine from the point of view of geography and population and to identify the most developed types of tourism in the region as well as their geospatial interdependence.

Presentation of the main research material.

Motor transport network in the Western region of Ukraine.

The network of public automobile roads in the Western region of Ukraine (Fig. 1) is 42,308.2 km, $98.2 \%$ of which have a hard covering.

Lviv and Khmelnytskyi oblasts have the largest length of public automobile roads in the region, Chernivtsi and Zakarpattia oblasts have the smallest length. Ivano-Frankivsk and Chernivtsi oblasts have $00 \%$ hard cover automobile roads. This indicator is lower in Zakarpattia (99.7\%), Ternopil (99.5\%), 


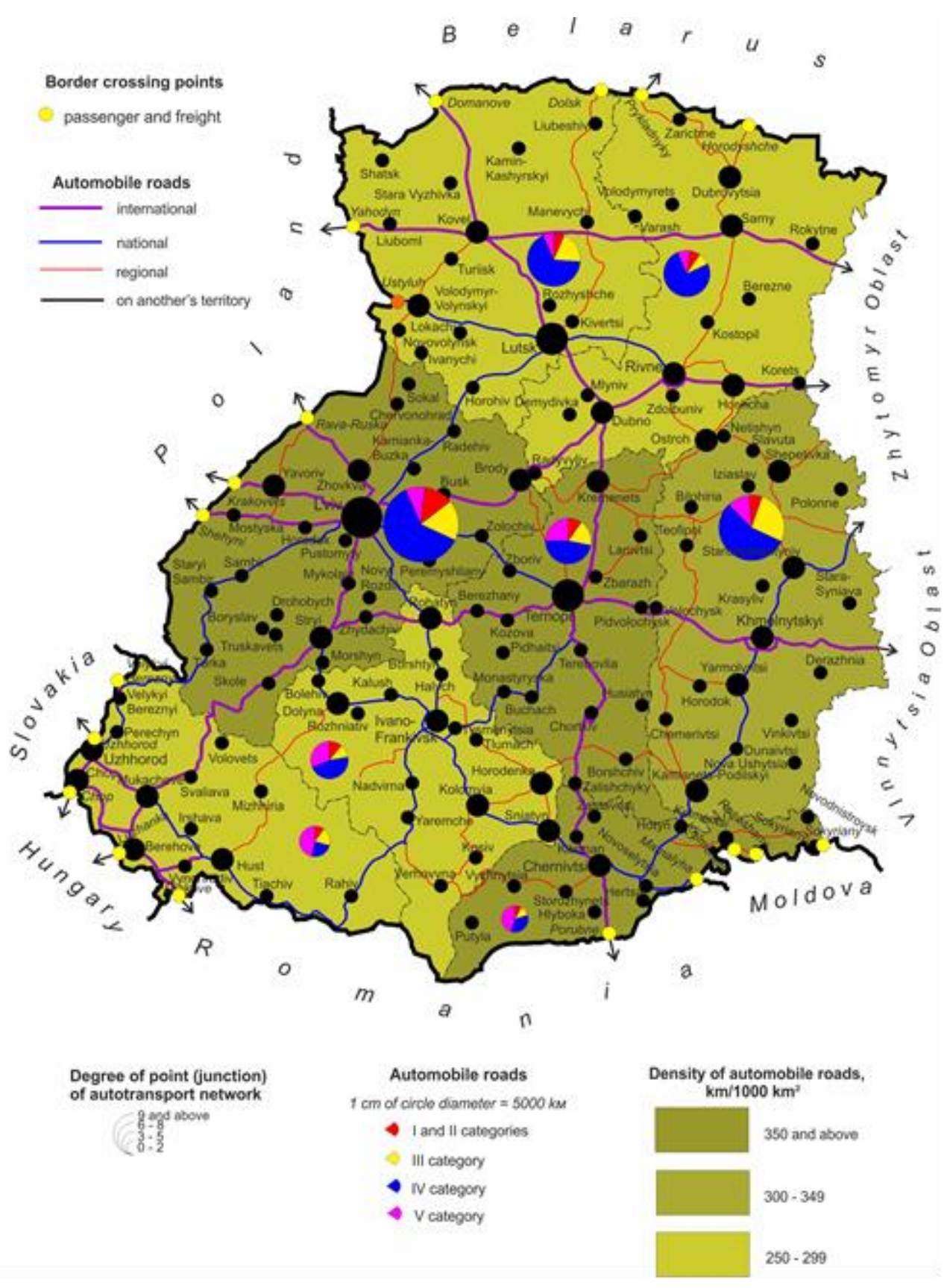

Fig. 1 Average density of public automobile roads in the Western region of Ukraine

Khmelnytskyi (99.3\%), Rivne (98.6\%), and Lviv (97.9\%) oblasts. The lowest share of hard covered automobile roads is in Volyn oblast (92.9\%).

The average density of public automobile roads in the Western region of Ukraine is $322 \mathrm{~km} /$ $1000 \mathrm{~km}^{2}$. The maximum values of public automobile roads density are typical for Lviv, Ternopil, Chernivtsi, and the minimum values - for Rivne and Zakarpattia oblasts. The average density of public automobile roads with hard covering for the Western region of Ukraine is $317 \mathrm{~km} / 1000 \mathrm{~km}^{2}$. As in the case of public automobile roads, maximum values of the density of automobile roads with hard covering are typical for Lviv $\left(376 \mathrm{~km} / 1000 \mathrm{~km}^{2}\right)$, Ter- nopil $\left(359 \mathrm{~km} / 1000 \mathrm{~km}^{2}\right)$, Chernivtsi $(358 \mathrm{~km} /$ $\left.1000 \mathrm{~km}^{2}\right)$, the minimum - for Rivne $(253 \mathrm{~km} \mathrm{/}$ $\left.1000 \mathrm{~km}^{2}\right)$ and Zakarpattia $\left(261 \mathrm{~km} / 1000 \mathrm{~km}^{2}\right)$ oblasts.

There is a direct interdependence between the indicators of the average density of public automobile roads and the number of hotel business enterprises in the Western region of Ukraine. The number of hotel enterprises located in these oblasts (Lviv, Chernivtsi oblasts) increases with the increase in the density of public automobile roads. The exception is Ivano-Frankivsk and Zakarpattia oblasts with rather moderate average density of public automobile roads compared to other administrative oblasts and a 
large number of hotel enterprises.

The maximum length of international automobile roads is in Lviv oblast, national - in IvanoFrankivsk and Lviv oblasts, regional - in Khmelnytskyi and Ivano-Frankivsk oblasts, and territorial in Khmelnytskyi, Volyn and Lviv oblasts. The automobile roads of I and II categories, technical parameters of which correspond most closely to modern European and world requirements, are $3987.7 \mathrm{~km}$ in the Western region of Ukraine, that is, $9.6 \%$ of the total length of the roads. Lviv oblast has the highest rate of such roads in the region $-26 \%$ of the total length of such automobile roads in the region. The lowest rate of automobile roads of I and II categories is in the Chernivtsi oblast $(6 \%$ of the length of these roads in the region). Almost in all oblasts of the Western region of Ukraine automobile roads of IV category predominate, while in Zakarpattia and Chernivtsi oblasts V category roads predominate.
Development of tourism in the Western region of Ukraine.

Tourism industry traditionally is one of the specialization areas in the economy of the oblasts in the Western region of Ukraine. In the tourism market, the region is distinguished by a significant proportion of sanatorium and spa establishments (about $8 \%$ of the total). There therapeutic rehabilitation is provided by about $11 \%$ of all healthcare establishments in Ukraine. The average indicator of use of places in these establishments reaches the level of $31-55 \%$. A significant proportion of hotel-type facilities (about $10 \%$ of the total) take about $8 \%$ of all tourists served in the country. However, the indicator of the hotel base is rather low (19-22\%). Tour operators and travel agencies occupy $8 \%$ of the nationwide number, while locals now serve more than $8 \%$ of foreign tourists (Fig. 2), of which $6 \%$ are in Lviv oblast.

Western region of Ukraine is attractive by the

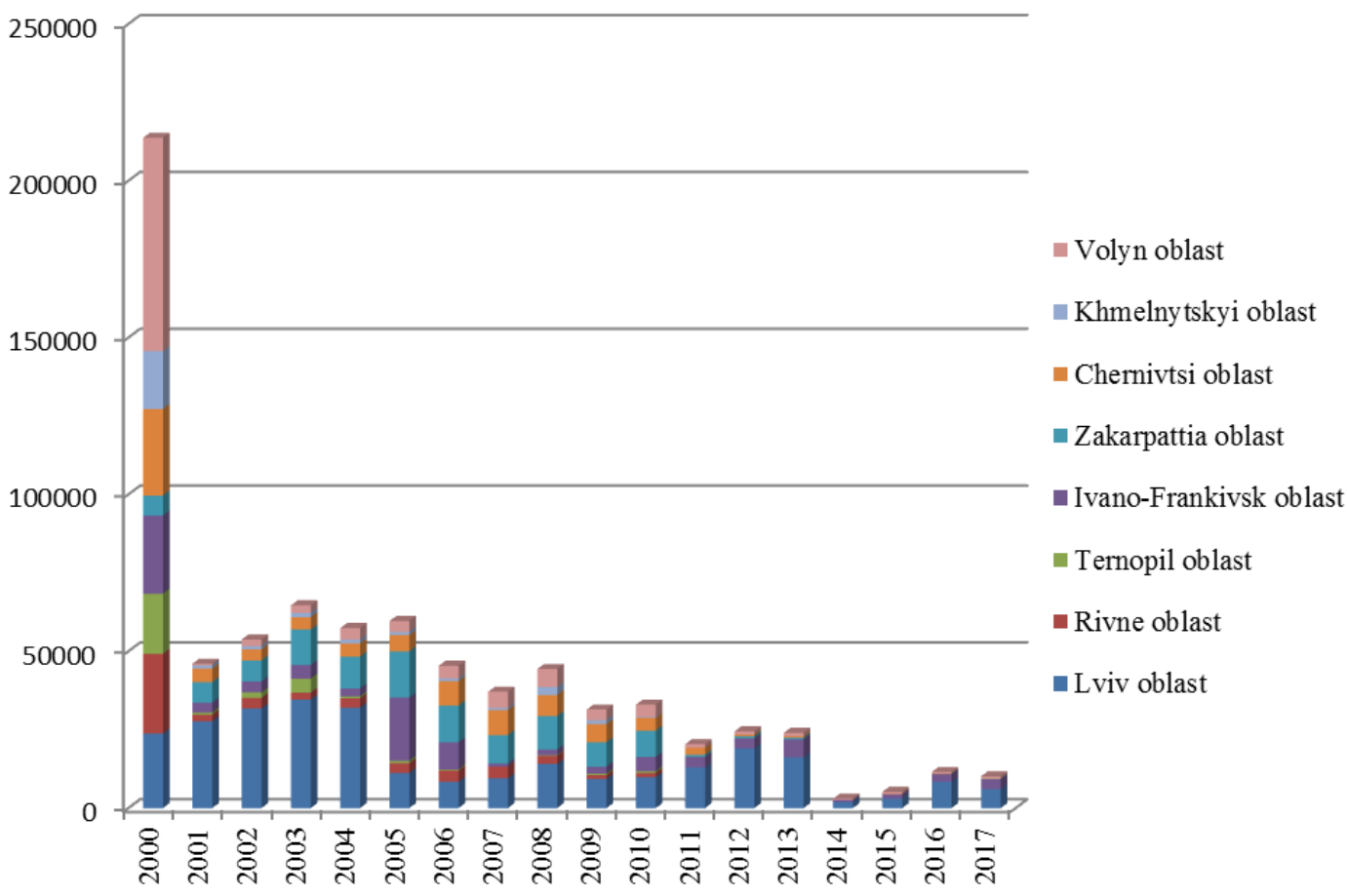

Fig.2. Dynamics of foreign tourists flows in the Western region of Ukraine, 2000-2017

following types of tourism: pedestrian, cycling, automobile, river, fishing, hunting, health, cognitive, professional and business, pilgrimage, nostalgic.

The health segment is one of the leading tourism industries in the Western region of Ukraine. Balneological and climatotherapeutic establishments provide a relatively high level of medical and preventive services. In Lviv and Ivano-Frankivsk oblasts there is a network of tourism areas with a significant concentration of such objects. These are, in particular, Truskavets (35 institutions), Morshyn (18), Opir and Stryi Valley (Slavske), Roztochya
(Nemyriv). In Ivano-Frankivsk oblast there are areas on the territory of the so-called Velykyi Yaremche (Yaremche, Mykulychyn and Vorokhta), as well as Kosiv, Sheshory and Dolyna. In Zakarpattia oblast, the tourism and receptive base is concentrated throughout the territory. Significant clusters of sanatorium and resort facilities are only in some resorts, such as Polyana, Synyak and Chynadiyevo, and recreational facilities - in the valley of the Uzh river in Mizhhirya.

The total length of the pedestrian paths is several hundred kilometers. However, there is no more 
detailed information on this issue, except for data on the length of roads in the territory of national parks and the Carpathian Biosphere Reserve. The most pedestrian trails have no indication, or it is outdated. In addition, there are a small number of wellequipped places for recreation. This is especially important on the hiking trails leading to the peaks of Chornogora and on the popular tourist trails on the Polonynskyi ridge, in the Gorgany and Beskydy.

Cycling tourism has become successful only in recent years, with the gradual spread of mountain bikes. There are too few adapted and marked bicycle tracks, located mostly in the vicinity of the towns of Skole and Yaremche.

Particular attention deserves river tourism, which is experiencing a kind of regeneration in the region. The appearance of modern equipment (kayaks, canoes, etc.) has created new opportunities for this kind of tourism on the Cheremosh, Prut, Stryi, Tysa and Dnister. Now the most popular are rafting and water slides on the Prut and Cheremosh. It is advisable to borrow Polish experience in using the rivers for this type of tourism in terms of identifying and streamlining tracks (parking and dock, hire points).

The Western region has significant opportunities for the development of hunting tourism due to a high degree of afforestation and rich fauna. Hunting is mainly engaged in special state and military forestry (Roztochya, Skolivski Beskydy, Gorgany), equipped with places for hunting and hunting lounges.

Another feature of the development of tourism industry in the region is cognitive tourism, which covers the main cities with many historical and cultural attractions, as well as architectural monuments. At the same time, there are certain obstacles and difficulties for more intensive development of certain types of cognitive tourism, such as the lack of auxiliary infrastructure of the appropriate level of service. At present, the drawbacks are the absence (except Lviv) of tourism information points near objects, special identification of routes of city tours and information tables near objects that damages the tourist image of cities and settlements of the Western region of Ukraine. In cities (raion centers) there is a community base no higher than the average standard (2-3 stars), as well as moderate prices per night. There are also problems associated with the organization of city walking routes, ensuring the proper functioning of museum institutions. There is a rich spiritual culture in Western Ukraine - ethnic customs and rituals, folk crafts (bedding, wickerwork, wood carving, weaving, straw weaving, traditional sheep breeding, authentic cuisine, etc.). The monuments of architecture IX-XX centuries - constructions of Lviv, Zhovkva, Pidhirtsi, Galych,
Uzhgorod, Mukachevo, Khotyn, Chernivtsi, archaeological monuments of international importance Trypillya settlements on the Dnister, Old Slavonic settlements in Stilske, Plisnesk, Zvenygorod, Vasyliv, Neporotove, Ruhotyn; the remnants of the ancient Galych in Krylos, the ruins of the rocky fortresses in Spas, Urych, Rozgirche, Bubnyshche, have particular importance for the development of cultural tourism. With regard to excursions to castles in Lviv and Zakarpattia oblasts, their readiness to accepting foreign tourists is considerably inferior to European models. The only exceptions are the castles in Olesk and Mukachevo, Uzhhorod, Zbarazh. In others restoration and upgrading works are in progress, there are no exhibits available for inspection, and the adjacent territories are not wellorganized. In addition, there is a lack of proper attendant support and accommodation and gastronomic base of the appropriate level.

Special development in the region has become cognitive tourism by natural tourism objects, due to a network of national parks and six landscapes (Sianskyi, Polyanytskyi, Halytskyi, Dnister Canyon, Verhniodnistrovski Beskydy, "Znesinnya" in Lviv). There are dozens of nature reserves, among which: Reserve of the Dovbush Rocks (Bubnyshche), Urytski Rocks, Maniavskyi Falls, Narcysy Valley, Europe Center (Dilove near Rakhiv). In recent years, tourism infrastructure has been prepared and modernized in national parks: natural museums, thematic trails (national parks Yavorivskyi, Carpathian, Uzhanskyi) have been created. However, it would be advisable to create a network of trails and didactic-ecological centers, through which it is possible to conduct classes on the promotion of protected areas. There are six national parks in the region Shatskyi, Yavorivskyi, Beskydy Skolivski, Synevyr, Uzhanskyi, Carpathian Biosphere Reserve, which allow developing specialized tourism (observation of nature, hunting with a camera, pedestrian, cycling, river tourism, etc.).

Nostalgic travel is an important component of the region's tourism development. Numerous monuments of nostalgic tourism continue to require support from the international community, funds for reconstruction and adaptation for the purpose of nostalgic tourism. These are the castles in Zhovkva, Pidgirtsi, Nevytske and Korolevo, as well as Jewish cemeteries and German village settlements in Lviv and Ivano-Frankivsk oblasts.

At the same time, as the direction of professional and business tourism, the Western region of Ukraine is popular among business people of the Ukrainian capital. This is probably due to the fact that traveling from other regions of Ukraine can take from 16 to 24 hours. However, the Western region is often used for motivational trips (ski tours as rew- 
ards for best employees or partners).

The largest centers of pilgrimage tourism in the Western region of Ukraine are St. George's Cathedral, the Assumption Church, the Polish Cathedral in Lviv, the Krekhiv Monastery (near Lviv), the Goshiv Monastery (Ivano-Frankivsk oblast). Zarvanytsya, located in Ternopil oblast, Zimnenskyi Svyatogorskyi Monastery (Zimne village of the Volyn oblast), Holy Trinity Mezhyritskyi Monastery XV-XVII centuries (Mezhyrich village, Rivne oblast), Holy Trinity Koretskyi Monastery XV-XVII centuries (Rivne oblast), Holy Trinity Dermanskyi Monastery, Fort XV-XVII centuries (Derman village, Rivne oblast), Svyatouspenska Univska Lavra (Peremyshlyany raion, Lviv oblast), Maniava Monastery (Ivano-Frankivsk oblast), Pidkaminets Monastery (Brody raion, Lviv oblast) are also worth visiting.

The development of automobile tourism is facilitated by the border oblast of the region, a network of automobile roads of national and international importance, as well as the intensive increase in the number of car owners in Ukraine over the last decade. In this connection, the development of road infrastructure is required. In recent years, the number of gas stations, service stations, motels, hotels, bars and cafes has considerably increased. However, the quantity and quality of the offered services is extremely insufficient. Given the regional situation at the intersection of international automobile roads, roadside infrastructure should increase at least several times to reach the level of neighboring countries. In order to revive international tourism, it is necessary to increase the number of border crossing points. According to the standards of the European Union, one border crossing point should be approximately $30 \mathrm{~km}$ border, whereas in the border oblasts of Ukraine, the distance between them is three or even four times higher.
Western oblasts in the Ukrainian tourism market have their specialization, formed on the basis of the range and level of services provided to tourists, as well as price policy. The tourism product of the region as a package, including visits, overnight stay, meals and transport, on the one hand, has retained its traditional specificity. On the other hand, it has gained new features related to innovations reflecting resource potential, as well as world trends. Traditional products, such as staying on holiday resorts, skiing, sightseeing, are now complemented by new ones, such as ethnically sentimental (visitors from neighboring countries and the Ukrainians living abroad), conference and ethnographic tourism.

Mutual influence of the motor transport network and tourism industry of the Western region of Ukraine

The analysis of transport and tourism spheres shows correspondences between them. There are many ways and criteria for classification of tourism types and here the focus is on two: the way of travel and the purpose of travel. The results of the analysis of correspondences are presented in two tables. They have a general trend character, allowing exceptions to certain unique situations. In parallel, it turns out that the types of tourism, highlighted by the way of travel, can be linearly arranged in accordance with the prevailing category of automobile roads.

Table 1 shows the trend correspondences between the types of tourism that are allocated by way of travel and are presented in the Western region of Ukraine and their accessibility in the main categories of automobile roads in the region. The last column "No automobile roads" in this table (and the following) concerns the territories of the region where there are no automobile roads. Categories of automobile roads are formulated by the last classification of 2006.

Table 1

Motor transport accessibility of types of tourism by the way of travel

\begin{tabular}{|c|c|c|c|c|c|c|}
\hline $\begin{array}{l}\text { Way of } \\
\text { travel }\end{array}$ & 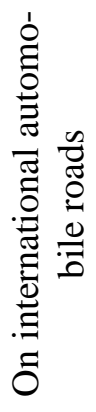 & 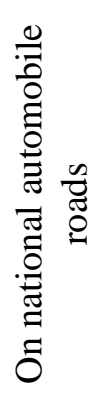 & 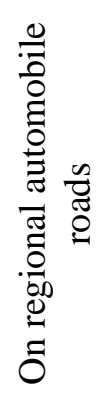 & 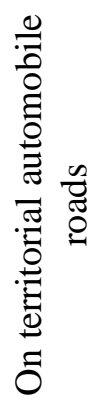 & 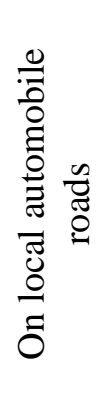 & 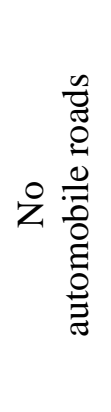 \\
\hline Automobile & + & + & + & + & + & \\
\hline Cycling & & + & + & + & + & \\
\hline Pedestrian & & & + & + & + & + \\
\hline River & & & & & & + \\
\hline
\end{tabular}


The automobile type of tourism uses travelling on all available automobile roads. However, on local automobile roads their quality can be rather low, but this is offset by the opportunity to see the deepseated highly attractive tourism objects. Traveling by car requires not only automobile roads, but also refueling and service stations.

Cycling type of tourism is localized on all types of automobile roads, except international. In some situations, fragments of cycling travels out the automobile roads are possible along the routes of existing trails in the area.

Pedestrian tourism logically avoids large automobile roads and tends to be difficult for transport areas, as well as to places where there are no roads of any kind at all.

River tourism in general is not tied to the network of automobile roads. Exceptions may be intersection points of rivers with motorways.

Table 2 shows the trend correspondences between the types of tourism that are allocated by the purpose of travel and are typical for the Western region of Ukraine and their accessibility in the main categories of automobile roads in the region. In parallel, it turns out that the types of tourism, allocated for the purpose of travel, can be linearly arranged in accordance with the prevailing category of automobile roads.

Motor transport accessibility of tourism by the purpose of travel

Table 2

\begin{tabular}{|c|c|c|c|c|c|c|}
\hline $\begin{array}{l}\text { Way of } \\
\text { travel }\end{array}$ & 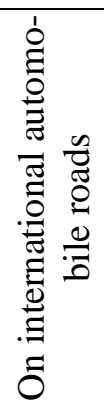 & 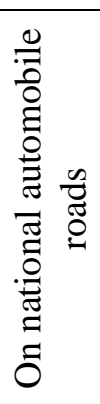 & 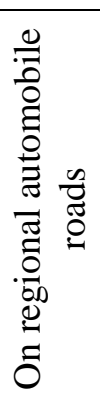 & 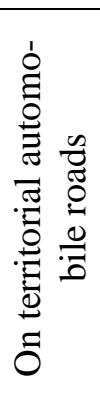 & 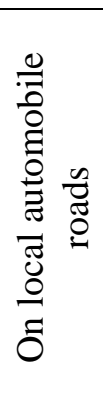 & 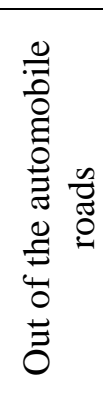 \\
\hline $\begin{array}{l}\text { Professional and } \\
\text { business }\end{array}$ & + & + & + & & & \\
\hline Cognitive & & + & + & + & + & \\
\hline Health & & + & + & + & + & \\
\hline Pilgrimage & & & + & + & + & \\
\hline Nostalgic & & & + & + & + & \\
\hline Fishing & & & & & + & + \\
\hline Hunting & & & & & + & + \\
\hline
\end{tabular}

Professional and business tourism logically tends to the administrative and business centers, which lie on the automobile roads of high and average level. Cognitive and health tourism are formally below the level. There is a difference between them because cognitive tourism tends to natural and historical and cultural objects, and health tourism tends to specialized health centers, mainly resorts, located in environmentally clean, distant from major motorways, areas.

Pilgrimage and nostalgic tourism occupy predominantly lower levels of road hierarchy, with some nostalgic travels to larger cities.

Fishing and especially hunting tourism logically tends to areas that are out of the automobile roads.

\section{Conclusions}

Density of public automobile roads in the Western region of Ukraine is quite high. In oblasts, in general, it corresponds to the level of tourism industry development (except Zakarpattia). The terri- torial gravity of the hotel business and tourist flows to the places of the developed network of automobile roads with amendment to the mountain areas of the Ukrainian Carpathians is observed.

According to the categories of automobile roads in the Western region of Ukraine, Lviv oblast has the best position, while Chernivtsi oblast has the worst position. The automobile roads of I and II categories, technical parameters of which correspond most closely to modern European and world requirements, are only $9.6 \%$ of total length of the roads in the Western region of Ukraine.

In the background of Ukraine, the Western region is allocated a large share of sanatorium and spa establishments (8\%), a significant proportion of hotel-type objects $(10 \%)$, a large share of all tourists $(8 \%)$, and the same rate of foreign tourists.

The Western region of Ukraine is attractive for pedestrian, cycling, automobile, river, fishing, hunting, health, cognitive, professional and business, pilgrimage, nostalgic tourism. 
An important factor in the development of tourism in the Western region of Ukraine is its border position on important trans-border motorways.

Western oblasts in the Ukrainian tourism market have their specialization, which is formed on the basis of the range and level of services provided to tourists, as well as price policy.

There is a trend correspondence between the types of tourism, allocated by way of travel and the prevailing category of automobile roads. Similarly, the dependence between the types of tourism, allocated for the purpose of travel and the prevailing category of automobile roads, is revealed. In both cases, the totality of tourism types can be linearly arranged according to the categories of roads, including a zero category "no automobile roads".

\section{References}

1. Головне управління статистики в Івано-Франківській області [Електронний ресурс]. - Режим доступу: http://www.ifstat.gov.ua/. - 11.05.2018 p. - Загл. з екрану.

2. Головне управління статистики у Волинській області [Електронний ресурс]. - Режим доступу: http://www.rv.ukrstat.gov.ua. - 11.05.2018 p. - Загл. з екрану.

3. Головне управління статистики у Закарпатській області [Електронний ресурс]. - Режим доступу: http://www.uz.ukrstat.gov.ua/statinfo/turism/ tur_potoki.pdf. - 11.05.2018 p. - Загл. з екрану.

4. Головне управління статистики у Львівській області [Електронний ресурс]. - Режим доступу: www.lv.ukrstat.gov.ua/ukr/si/year/2016/ t249916_1.pdf. - 11.05.2018 p. - Загл. з екрану.

5. Головне управління статистики у Рівненській області [Електронний ресурс]. - Режим доступу: http://www.rv.ukrstat.gov.ua. - 11.05.2018 p. - Загл. з екрану.

6. Головне управління статистики у Тернопільській області [Електронний ресурс]. - Режим доступу: http://www.te.ukrstat.gov.ua/files/T/T1.htm. - 11.05.2018 p. - Загл. з екрану.

7. Головне управління статистики у Хмельнищькій області [Електронний ресурс]. - Режим доступу: http://www.km.ukrstat.gov.ua/ukr/index.htm. - 11.05.2018 p. - Загл. з екрану.

8. Головне управління статистики у Чернівещькій області [Електронний ресурс]. - Режим доступу: http://www.cv.ukrstat.gov.ua/. - 11.05.2018 p. - Загл. з екрану.

9. Грицевич, В.С. Географія людини в інформаційному суспільстві [Текст] / В.С. Грицевич // Регіон-2011: Стратегія оптимального розвитку: матеріали міжнар. наук.-практ. конф. - Харків: РВВ Харківського наиіонального ун-ту ім. В.Н. Каразіна, 2011. - С. 21-23.

10. Грицевич, В.С., Подвірна, Х.С. Готельні заклади Львівщини та їхня діяльність на прикладі міжнародного туризму [Текст] / В.С. Грищевич, Х.С. Подвірна // Часопис сочіально-економічної географії. - 2012. Bun. 12(1). - C. 97-101.

11. Грищевич, В.С., Подвірна, Х.С. Міжнародний туризм у Карпатському регіоні України: регіональні аспекти та розвиток [Текст] / В.С. Грищевич, Х.С. Подвірна // Науковий вісник Волинського наиіонального ун-ту ім. Лесі Украӥнки. Географічні науки. - 2012. - №18. - С. 170-175.

12. Грицевич, В.С. Проект залізничної круїзної діяльності на прикладі Західного регіону Украӥни [Текст] / В.С. Грицевич // Перспективи розвитку індустрії туризму в Украйні: матеріали міжвузівської викладацької науково-практичної конферениії, 5 грудня 2013 року. - Львів: ЛІЕТ, 2014. - С. 23-26.

13. Грицевич, В.С., Сеньків, М.I. Топологія і метрика автотранспортного простору, як чинник транспортнологістичної діяльності [Текст] / В.С. Грицевич, М.I. Сеньків // Геополитика и экогеодинамика регионов. 2014. - Том 10, Bыn. 2. - C. 483-488.

14. Гричевич, В.С., Сеньчук, Х.В. Історико-географічні особливості розвитку залізничної мережі в Західному регіоні Украӥни [Текст] / В.С. Грицевич, Х.В. Сеньчук // Наукові записки Тернопільського національного педагогічного університету. Географія. - 2008. - №2. - C. 6-12.

15. Грииевич, В.С., Сеньчук, Х.В. Полімагістралі Карпатського регіону Украӥни [Текст] / В.С. Гричевич, Х.В. Сеньчук // Наукові записки Тернопільського національного педагогічного університету. Географія. 2011. - №2. - C. 78-83.

16. Грицевич, В.С. Суспільно-географічне пізнання світу як наукова категорія і важлива сфера людської діяльності [Текст] / В.С. Грицевич // Регіональні проблеми Украйни: географічний аналіз та пошук шляхів вирішення: зб. наук. прачь. - Херсон, 2009. - С. 133-136.

17. Grytsevych, V., Senkiv, M. Transport and logistic potential of the Western Ukrainian borderland [Text] / V. Grytsevych, M. Senkiv // Journal of Geography, Politics and Society. - 2017. - Vol. 7 (2). - P. 81-86.

18. Feng, Z. Tourism and Transport: Modes, Networks and Flows [Text] / Z. Feng // Tourism geographies. - 2010. Vol. 12 (4). - P. 579-582.

19. Podvirna, Kh. Logistical aspects of international tourism activity of Ukraine [Text] / Kh. Podvirna // World Science. Scientific and Practical Results in 2015. Prospects for Their Development: Proceedings of the International Scientific and Practical Conference. - Abu-Dhabi (UAE), 2016. - P. 52-55.

20. Taylor, Z., Ciechanski, A. Transport means and organised tourism: empirical evidence from Poland [Text] / Z. Taylor, A. Ciechanski // Geographia Polonica. - 2016. - Vol. 89 (4). - P. 485-504.

Authors Contribution: All authors have contributed equally to this work. 
UDC 911.3:338.4

Volodymyr Stefanovych Grytsevych,

$\mathrm{PhD}$ (Geography), Associate Professor, Department of Economic and Social Geography,

Ivan Franko National University of Lviv,

PO Box 2137, Lviv-7, 79007, Ukraine,

e-mail: gvsmg@ukr.net, https://orcid.org/0000-0002-0278-7332;

Khrystyna Yevgenivna Podvirna,

$\mathrm{PhD}$ (Geography), Associate Professor of the Department of International Economics and Investment,

Lviv Institute of Economics and Tourism,

8 Mentsynskyi str., Lviv, 79007, Ukraine,

e-mail: khrystyna.pod@gmail.com, https://orcid.org/0000-0002-0828-9078;

Mariana Igorivna Senkiv,

$\mathrm{PhD}$ (Geography), Assistant of the Department of Tourism, Lviv Polytechnic National University,

130 General Chuprynka str., Lviv, 79057, Ukraine,

e-mail: mariana.i.senkiv@lpnu.ua, https://orcid.org/0000-0002-2146-3456

\section{MOTOR TRANSPORT NETWORK IN THE WESTERN REGION OF UKRAINE AS A FACTOR OF TOURISM INDUSTRY DEVELOPMENT}

Formulation of the problem. Infrastructure can be a factor of certain industries' development in the service sector. Conversely, the development of the service sector may stimulate infrastructure development.

Analysis of recent research and publications. Most of the research is devoted to issues of infrastructure and services separately, but not to the mutual influence of infrastructure and services.

Selection of previously unsettled parts of the general problem. For studying the peculiarities of the mutual influence of the motor transport network and specific types of tourism in the Western region of Ukraine the motor transport infrastructure was considered as part of general infrastructure and tourism industry as part of service sector.

Formulating the purpose of the paper. The purpose of the paper is the human and geographical analysis of the motor transport network of the Western region of Ukraine and spreading of the most developed types of tourism in the region in order to identify the features of their geospatial interdependence.

Presentation of the main research material. The network of public automobile roads in the Western region of Ukraine is rather dense, which corresponds to the level of development of the tourism industry in the oblasts. There is a territorial gravity of the subjects of the hotel business and tourist flows to the places of a developed network of automobile roads.

In order to analyze the motor transport and tourism spheres for correspondences between them, two classification criteria of types of tourism are selected: according to the way of travel and the purpose of travel. The types of tourism identified for each criterion can be linearly ordered in accordance with the predominant category of automobile roads.

Conclusions. Automobile type of tourism uses the ways of travel on all available automobile roads. Cycling type is localized on all types of automobile roads, except international motorways. Pedestrian tourism tends to places where there are no roads of any class at all.

Business tourism tends to the administrative and business centers that are on the priority automobile roads. Cognitive tourism tends to the natural, historical and cultural objects, while health tourism tends to the specialized health centers, mainly resorts. Pilgrim and nostalgic tourism occupy mostly lower levels of the hierarchy of automobile roads, although some nostalgic travels can be found in large cities. Fishing and, especially, hunting tourism tends to areas with no automobile roads.

Keywords: motor transport, roads, network, gravity, tourism, flow, oblast, region.

\section{References}

1. Main Statistical Office in Ivano-Frankivsk oblast. Available at: http://www.ifstat.gov.ua.

2. Main Statistical Office in Volyn oblast. Available at: http://www.lutsk.ukrstat.gov.ua.

3. Main Statistical Office in Zakarpattia oblast. Available at: http://www.uz.ukrstat.gov.ua/statinfo/ turism/tur_potoki.pdf.

4. Main Statistical Office in Lviv oblast. Available at: http://www.lv.ukrstat.gov.ua/ukr/si/year/2016/t249916_1.pdf 24.

5. Main Statistical Office in Rivne oblast. Available at: http://www.rv.ukrstat.gov.ua.

6. Main Statistical Office in Ternopil oblast. Available at: http://www.te.ukrstat.gov.ua/files/T/T1.htm.

7. Main Statistical Office in Khmelnytskyi oblast. Available at: http://www.km.ukrstat.gov.ua/ukr/index.htm.

8. Main Statistical Office in Chernivtsi oblast. Available at: http://www.cv.ukrstat.gov.ua. 
9. Grytsevych, V.S. (2011). Human Geography in the Information Society. Optimal development strategy, 21-23.

10. Grytsevych, V.S, Podvirna, Kh.E. (2012). Hotel establishments of Lviv oblast and their activities on the example of international tourism. Journal of Social and Economic Geography, 12 (1), 97-101.

11. Grytsevych, V.S, Podvirna, Kh.E. (2012). International tourism in the Carpathian region of Ukraine: regional aspects and development. Scientific herald of the Volyn National University named after Lesia Ukrajinka. Geographical Sciences, 18, 170-175.

12. Grytsevych, V.S. (2014). The project of railway cruise activity on the example of the Western region of Ukraine. Prospects for the development of the tourism industry in Ukraine: materials of the Interuniversity Teaching and Practical Conference. Lviv (Ukraine), 23-26.

13. Grytsevych, V.S, Senkiv, M.I. (2014). Topology and metric of motor transport space as a factor of transport and logistics activity. Geopolitics and eco-geodynamics of the regions, 10 (2), 483-488.

14. Grytsevych, V.S, Senchuk, Kh.V. (2008). Historical and geographical features of the development of the railway network in the Western region of Ukraine. Scientific notes of the Ternopil National Pedagogical University. Geography, 2, 6-12.

15. Grytsevych, V.S, Senchuk, Kh.V. (2011). Polymagistrals of the Carpathian region of Ukraine. Scientific notes of the Ternopil National Pedagogical University. Geography, 2, 78-83.

16. Grytsevych, V.S. (2009). Human and geographical knowledge of the world as a scientific category and an important sphere of human activity. Regional problems of Ukraine: geographic analysis and the search for solutions, $133-136$.

17. Grytsevych, V., Senkiv, M. (2017). Transport and logistic potential of the Western Ukrainian borderland, Journal of Geography, Politics and Society, 7 (2), 81-86.

18. Feng, Z. (2010). Tourism and Transport: Modes, Networks and Flows. Tourism geographies, 12 (4), $579-582$. doi:org/10.1080/14616688.2010.516767.

19. Podvirna, Kh. (2016). Logistical aspects of international tourist activity of Ukraine. International Scientific and Practical Conference "World Science" (Proceedings of the International Scientific and Practical Conference "Scientific and Practical Results in 2015. Prospects for Their Development”). Abu-Dhabi (UAE), 1, 52-55.

20. Taylor, Z., Ciechanski, A. (2016). Transport means and organised tourism: empirical evidence from Poland. Geographia Polonica, 89 (4), 485-504. https://doi.org/10.7163/GPol.0070. 